\title{
The Gardens of the Lord: A Description of the Moravian Church in Labrador, and the Lande Collection, entitled "The Moravian Missions to the Eskimos of Labrador"'
}

by Davena Davis

For almost two centuries the Moravian Church maintained a mission in Labrador to bring the Christian message to the Inuit and later to the European settlers living along Labrador's northern coast from Cape Harrison to Cape Chidley. Over the years several communities grew up around the mission stations at Nain, Hopedale, Ramah, Zoar and Makkovik. The missionaries of this small Protestant, originally German-speaking, denomination spent most of their adult years with the Inuit, ministering to them, teaching them and caring for their physical needs. Until 1926 they also dominated the import and export trade along the northern Labrador coast. Until recently, the mission staff maintained exhaustive records of the missions and of their business enterprise. In the 1960s all of this material (except parish registers) was removed from Labrador. Much of the library became the nucleus of the Lande Eskimo Collection which is a unique collection of primary and secondary material such as Inuktitut Scripture texts, catechisms and bymnals, basic reading and arithmetic aids, German-language bistory and geography books and several runs of mission periodicals.

Pendant près de deux siècles, l'église morave a tenu une mission au Labrador dans le but de christianiser les Inuit et, par la suite, les colonies d'Européens venus s'établir sur la côte nord du Labrador, entre Cap Harrison et Cap Chidley. Au fil des ans, plusieurs communautés se sont implantées autour des missions: Nain, Hopedale, Ramab, Zoar et Makkovik. Les missionnaires de ces petites communautés protestantes qui, à l'origine, s'exprimaient en allemand, ont consacré l'essentiel de leur vie aux Inuit, leur inculquant les rudiments de la foi, les éduquant et les soignant. Jusqu'en 1926, ils ont également exercé un contrôle étroit sur les importations et les exportations de la côte nord du Labrador. Jusqu'à dernièrement, les missionnaires ont tenu des rapports exbaustifs sur leurs différentes activités, aussi bien humanitaires que commerciales. Dans les années 1960, tous ces documents (à l'exception des registres paroissiaux) ont quitté le Labrador pour former l'essentiel de la collection eskimo Lande. Celle-ci réunit un ensemble unique de documents secondaires et primaires, notamment des textes en inuktitut, des catéchismes et des hymnes, des manuels de lecture et de mathématiques, des livres d'histoire et de géographie en allemand et plusieurs périodiques traitant des missions. 
The Gardens of the Lord

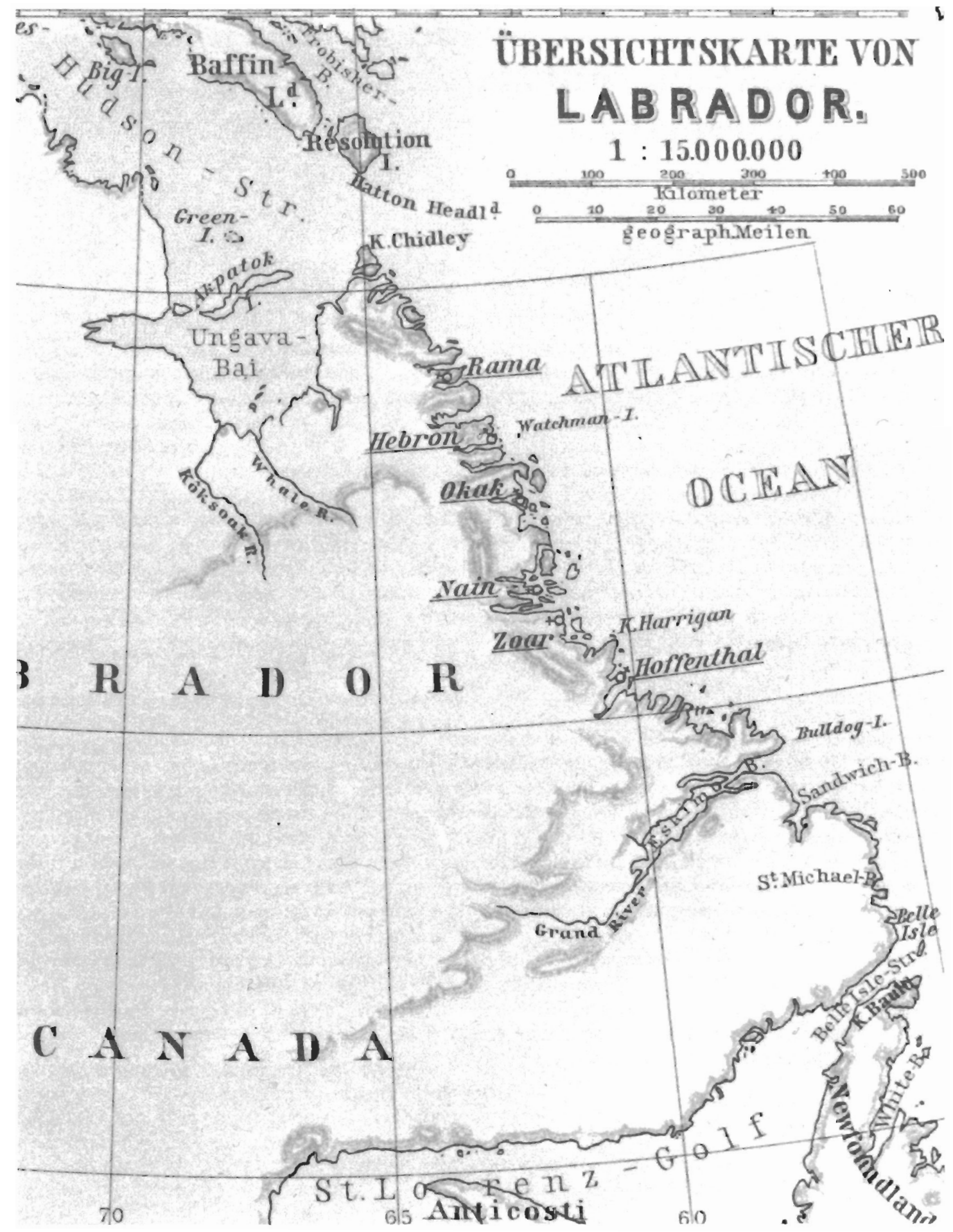

Figure 1. The Labrador coast in the 1890s. Atlas der Brüdergemeine. Herrhut: Expedition der Missionsverwaltung, 1895. (Esk 68). 


\section{The Gardens of the Lord}

Sheltered from the north, and nestled in a small valley where a few trees gave some signs of life and beauty to the otherwise barren scenery, were placed a number of buildings. These consisted of a dwelling house, a church, stores and a shed for wood....

The fine spacious church, so plain and so clean, was just suited to the needs of the Eskimo. The dwelling-house is built in a strong, substantial manner, and every room is utilized to the best advantage... My wonder grew deeper still when I went into the garden, where a number of choice vegetables were growing....

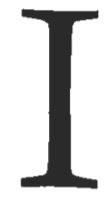

$\mathrm{n}$ the summer of 1909 Edmund $\mathrm{J}$. Peck, a missionary in the employ of the Church of England's Church Missionary Society, ${ }^{2}$ was en route to Baffin Island where the CMS had had a mission to the Inuit since 1894. The ship on which he was travelling made several stops, one of which was at Hopedale, a village on the coast of Labrador. Peck, like many missionaries, kept a journal of his experiences as eviclenced by the brief entry above.

\section{The Mission}

Hopedale was one of several Inuit communities established by the missionaries of the Moravian Church. A number of other communities or villages along the northern coast of Labrador were also settled at the instigation of the Moravian missionaries: Nain (1771), Okak (1775), Hebron (1830), Zoar (I 864 or 1866 ) and Ramah (1871). Hopedale itself dates from 1782. ${ }^{3}$

As early as 1752 the Moravians had shown an interest in establishing a mission in Labrador. By this time they had had the opportunity to see the results of their evangelization in Greenland begun some twenty years before. The first attempt to set up a mission in Labrador ended in disaster, however, with the death of four missionaries at the hands of some Inuit. By 1771, through the efforts of one or two determined missionaries and several influential British Moravians, permission had been secured from the British Privy Council for the founding of a mission in Labrador. Nain was established first, with Okak and Hopedale following in the next decade (Figure 1).

Apart from the building of these three centres, the real work of the mission, the evangelization of the Inuit, progressed slowly. At the beginning the Inuit were reluctant to exchange their religion and their customs for those of the Europeans newly arrived in their midst.
However, in 1804 there took place what has been called an "awakening," and several Inuit presented themselves for baptism. From that time on, the efforts of the missionaries met with success; the Inuit living in and around the Moravian villages were all Christians. For Peck, who was attempting a century later to do the same work among the Baffin Island Inuit, the sight of a Christian lnuit population and a wellestablished mission was encouraging indeed.

Others view the mission less favourably ${ }^{4} \mathrm{~A}$ major criticism of the Moravian missionary activity in Labrador (as in west Greenland where the church also had a mission) focuses on the Church's policy of concentrating population in villages around the mission stations. This was contrary to the traditional nomadic lifestyle of the Inuit, and is thought to have contributed to the declining Inuit population in northern Labrador. On the other hand, by what other means could the missionaries have accomplished their goal? An interpretation of the mission which is satisfactory to all, and does justice to the intent of the missionaries, is difficult to reach.

The missionaries' goal was two-fold. Clearly, sharing the Christian gospel was the overwhelming objective. Moravians had been filled with missionary zeal since 1731. To use the twentieth-century term, "missionary outreach" was one result of a spiritual renewal which had taken place on August 13, 1727, among a community of Protestants in Herrnhut, Saxony, Germany. "Renewal" in this case was not merely spiritual re-birth, it was also the rebirth of a church which had come into existence some three centuries earlier and had virtually disappeared after the Thirty Years' War (1618-1648). Among the community at Herrnhut were several Moravians and Bohemians who considered themselves descendants of the Moravian Brethren, the name adopted by some of the followers of Jan Hus (1371-1415) who was 


\section{The Gardens of the Lord}

condemned by the Council of Constance and executed. The Herrnhut community had been formed through the initiative of Nicolaus Ludwig von Zinzendorf (1700-1760), a Lutheran Pietist. In 1722 Zinzendorf offered asylum to several Protestant Moravian and Bohemian families who were living in territories which, since 1627 , had disallowed freedom of worship. Secret observance allowed some vestiges of Protestantism to endure. Thus through the spiritual experience of August 13, 1727, the community at Herrnhut became the renewed Church of the Unity of the Brethren or Unitas Fratrum, Moravian Brethren or Moravian Church. It is by the latter name that this denomination is best known today in Great Britain and North America.

That religious experience re-shaped the whole community. They drew more adherents and, in the years of the religious awakening in Europe and North America in the eighteenth century, spread throughout central and western Europe, Great Britain, the West Indies and America. The first missionaries went to the West Indies in 1732; a mission to Greenland was established in 1733; and, as mentioned above, a mission in Labrador was attempted as early as $1752 .^{5}$

The secondary goal in Labrador (as in a few other of their missions) was the operation of a business. In Labrador a Moravian business enterprise, the Society for the Furtherance of the Gospel (SFG) held a monopoly on trade with the Inuit. The SFG, through the missionaries, controlled the stores in which the Inuit traded or sold their yearly harvest of fur and fish. The SFG determined the imports and exports from the Labrador coast north of Cape Harrison and set the prices based on the London market (Figure 2).

This encroachment of the secular world into the spiritual has been another area of criticism in recent years and gradually came to be questioned by many of the Moravians themselves. Ostensibly, the trade carried on with the Inuit was to develop in them a notion of thrift and to save them from dealings with unscrupulous traders. The profits, when there were profits, defrayed the cost of this expensive northern mission. According to the records, however, losses werc more common than profits. ${ }^{6}$ By the late nineteenth century, it was becoming clear that the business enterprise was not achieving its aims. The Inuit were travelling south to trade with private traders and with the Hudson's Bay Company; they were gravely indebted to the SFG as well as to other trading companies; and the business was operating at a loss. However, the decision to withdraw from trade was not made until 1926, when the entire business enterprise was transferred to the Hudson's Bay Company.

Poor years were not uncommon on the Labrador coast. Life was harsh for everyone Inuit, settlers ${ }^{7}$ and missionaries alike. The privations of the missionaries were not those of the Inuit nor of the settlers; they had a permanent building in which to live, enough wood to heat it and sufficient, if not excessive, food. And, as the Anglican missionary Peck observed, they had fresh vegetables. They lacked none of the basic necessities of life, but the socalled luxuries - friends, family, privacy, freedom - were abandoned to missionary service. Postings, at least to Labrador, were normally for periods of between thirty and forty years. In Labrador the missionaries endeavoured to become integrated and identified with the native community. Short-term stays and frequent furloughs would have been inconsistent with Moravian missionary philosophy.

Each station had a staff of at least one couple; the larger stations had two or three couples with, from time to time, an unmarried man. Common housing was the practice until early in this century with only one dwelling house at each station. The household chores were shared in turn. Children were sent away to Moravian boarding schools in Lurope as soon as they were of an age to travel

The Moravian lifestyle was an expression of their faith. Daily personal and family prayers, Bible-reading, a sober and earnest demeanour typified the Moravian lifestyle. Traditional Moravian worship services were dist inctive with a strong musical component. Up to a point, the missionaries endeavoured to shape the Inuit along Moravian lines. T'o what extent they attempted this and to what extent they succeeded are two more difficult and complex questions about this mission. The more perceptive of the missionaries realized that their role was not to make European Christians out of the Labrador Inuit. They did expect, however, 
The Gardens of the Lord

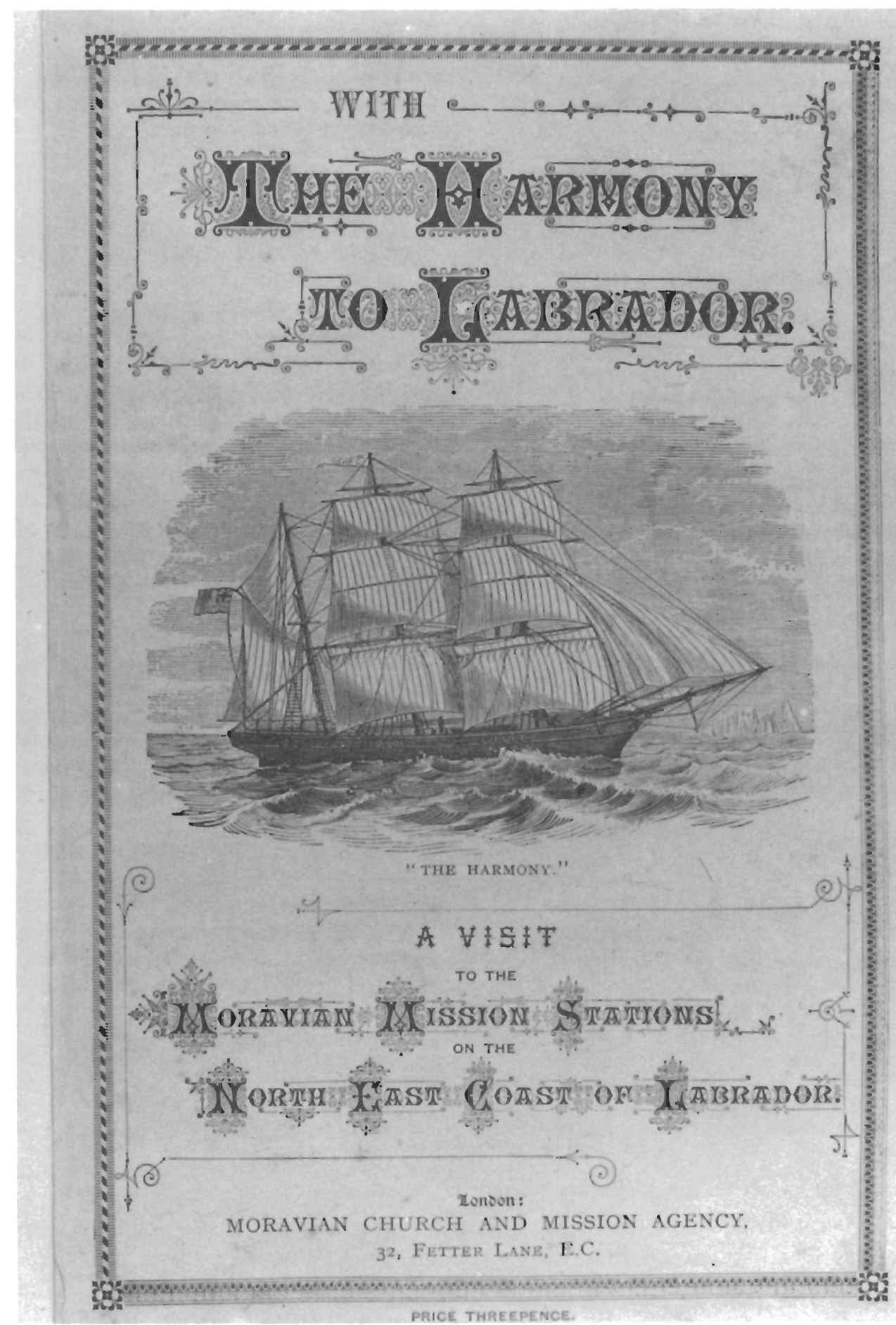

Figure 2. The Rev. Bejamin La Trobe's account of his visit to Labrador, ca. 1888. (Esk 65). 
Suptraction ubvalo Illangerterinek.

23. 45678

$26+39$

2.. 7584357

284356

24. 64387

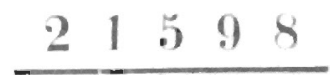

26. $\quad 8 \quad 3 \quad 7 \quad 0 \quad 0 \quad 8$

\begin{tabular}{llllll}
6 & 4 & 5 & 6 & 3 & 8 \\
\hline
\end{tabular}

Orunga tikkilugo Nummerit idluartomik aglaksimalaukputillusinginik tukkisilerkorlutit. Taimak malliktut aglareksaumirut, oktutigijetitut maunga tikkilugo. Tamãt unnunerset illangerteksauvlutik, kolãnut. Ikkinerselle illangerterijovlutik atãnut.

27. 12 illangerterkit 8 enik.

28. 16 illangerterkit 10 enik.

29. 20 illangerterkit 11 enik.

30. 21 illangerterkit 6 enik.

31. 100 illangerterkit 56 enik.

32. 2.58 illangerterkit 135 enik.

Figure 3. Subtraction flashcard. 186? (Esk 32). 
to make Christians of them, and in this they succeeded. Nevertheless, on both sides expectations of behaviour were constantly changing.

This became especially critical by the late nineteenth century when the missionaries ceased to be the only Europeans with whom the Inuit came into contact. The northern Labrador coast was becoming accessible to fishermen, explorers and adventurers. The tenor of life began to change, and no longer were the Moravians the influence they had been. The First World War, the transfer of the business enterprise from the SFG to Hudson's Bay Company in 1926, the involvement of the New foundland government in Labrador in the 1920 s and 1930 s and radio communication completely altered the life of the missions and of the lnuit.

The spiritual and temporal centre of the Moravian Church had been at Herrnhut since its founding although the Church had spread into Great Britain and the United States. The majority of missionaries stationed in Labrador were German-speaking and were subjects of Kaiser Wilhelm ll when the First World War broke out. The hostilities affected northern Labrador very little and with a few exceptions the missionaries stayed at their posts, but after the War the vast Moravian missionary enterprise was divided along political lines; the British Moravian Church became responsible for all Moravian missions within the existing British empire. In Labrador the staff gradually changed.

At the present time, the Moravian communities in Labrador are affiliated with the American Moravian Church whose northern headquarters are located in Bethlehem, Pennsylvania.

\section{The Collection}

In the early 1960s, records (excluding parish registers) dating back to the $1700 \mathrm{~s}$ were microfilmed by the Public Archives of Canada and transferred from the various Labrador mission stations to the Moravian Archives in Bethlehem. The missionaries kept thorough records which are of great value to researchers and historians interested in northern Labrador. ${ }^{8}$ A station diary which recorded the spiritual and economic progress (and sometimes relapse) of the community, annual conference letters from the missions and annual letters from the mission headquarters in Herrnhut and from the SFG are among the records transferred. All give a picture of life at the missions year by year, together with annual mission or commercial policies Voluminous correspondence was carried on between the missionaries in Labrador and mission authorities in Herrnhut and with the SFG in London. Copies were retained at the time of writing, and these, too, offer readers an intimate view of life in Labrador from the 1700 s to the late 1950s.

At about the same time as the records were transferred to Bethlehem, the collection of books and periodicals which the missionaries had acquired over almost two hundred years was dispersed among several sources. The Moravian Mission to the Eskimos of Labrador, a collection of some two hundred titles reflecting the broad range of interests and backgrounds of the missionaries stationed over the years at the various mission stations, is one of the results of this dispersal. ${ }^{9}$ 'The Moravian Collection forms part of the Lawrence Lande Collection of Canadiana in the Department of Rare Books and Special Collections, McLennan Library. Included are the expected scriptures translated into Inuktitut and catechisms in the same language. ${ }^{10}$ A few examples of the liturgies for which the Moravian Church is renowned are also present in the collection, together with hymnals in Inuktitut and some German (Figure 3). Music played an important part in the public and private worship of both the missionaries and the Labrador Inuit.

Apart from aids to worship and devotional literature, the Moravian Collection reflects the missionaries' commitment to education - both the furtherance of their own, and that of the people to whom they were ministering. There are a few German language history and geography books perhaps intended as "continuing education" but possibly purchased as source material from which to teach the Inuit. Basic arithmetic and reading books and cards were prepared by the missionaries and printed either on site or in London or at one of the Moravian publishing houses in Europe (Figure 4). The missionaries encouraged the Inuit to develop reading and writing skills in their own language, but did not actively teach English, the language of the European settlers and traders in Labrador, until this century. For most of the 

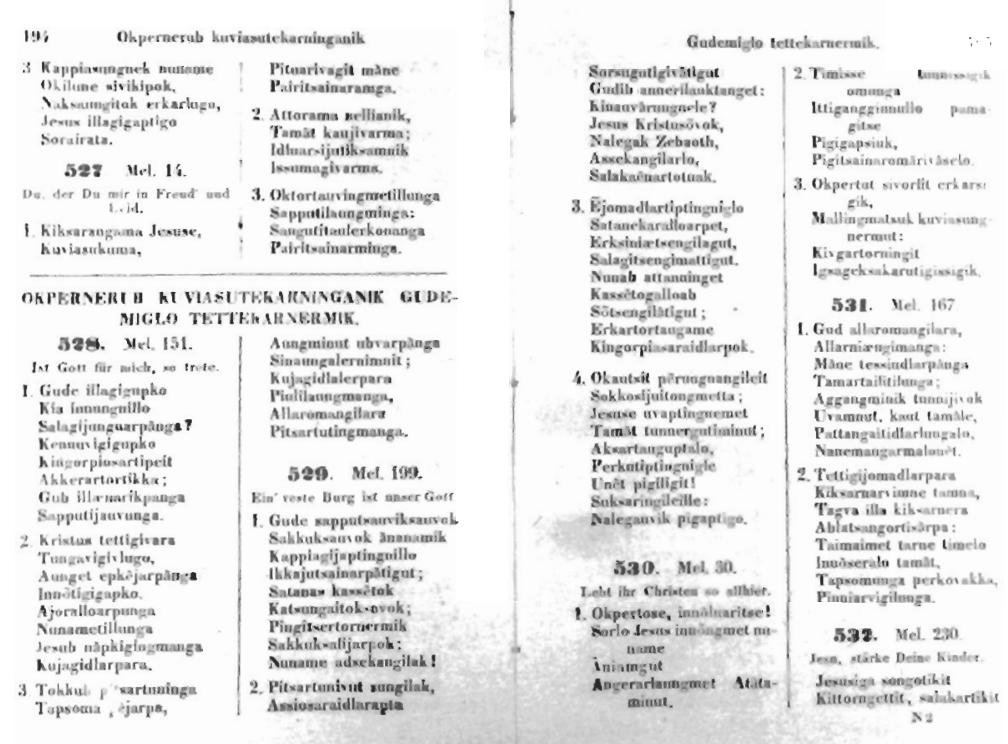

Figure 4. Luther's hymn "Ein feste Burg ist unser Gott" (No. 529) in Inuktitut. Imgerutit attorekst illagẽktunnut Labradoremẽtunnut. Loebaume: J.A. Duroldtib Nenilauktangit, 184 ? (Esk 26).

missionaries it was a second, if not unknown, language although it had been the custom even before this century to have one or two Englishspeaking couples on the staff. In the late 1800 s it became evident to the Mission Board in Herrnhut and the SFG in London that there was a need to minister to the English-speaking settlers in the area around Makkovik. By 1893, the missionaries were offering the services of a Protestant church to the English-speaking settlers in the area.

The missionaries were also virtually the only suppliers on the northern Labrador coast of medicine and medical treatment until 1894, when Wilfred Grenfell made the first of many visits to the Labrador coast. The collection includes a number of medical books reflecting this responsibility; of particular interest is Joseph Romig's treatise, A Medical Handbook for Missionaries in Cold Climates. "Romig was an American Moravian doctor and missionary in Alaska, and this may well have been the first medical book of its type.

Missions, understandably, occupied an important place in the lives and interests of these missionaries, and the Moravian collection contains a number of books about Protestant missions throughout the world. In this category, also, are several runs of mission periodicals, the most well-known being the Moravian periodical Nachricbten aus der Brüdergemeine (1819-1894). This contains accounts from all the Moravian missions, annual statistics and editorials from the Mission Board. ${ }^{12}$ From time to time, a brief biography or autobiography of a missionary was included. It was a custom among Moravians to write (or have written) a Lebenslauf, a type of autobiography, paying particular attention to the person's spiritual development. Accounts of this sort provided spiritual edification to the readers of the Nachrichten and give twentieth-cent ury mission historians an intimate glimpse into the mindset and world of an eighteenth-century Moravian missionary.

In the initial contact periods, Christian missionaries had to rely on interpreters for the dissemination of their message. Clearly this was not an ideal arrangement, and among their first tasks missionaries attempted to learn the languige of the people to whom they were ministering. (irammars and dictionaries were for them language tools of the future. It was for 
succeeding generations of missionaries to compile and publish such books. Now, indeed, all we know of a few of the languages of North America's native peoples comes from missionaries' grammars and dictionaries. The languages themselves are no longer spoken. Within the Moravian Collection is a Grammar of the Language of the Lenni Lenape or Delaware Indians, ${ }^{13}$ compiled by David Zeisberger (1721-1808), a Moravian missionary to the Delaware (or Moravian) Indians, as well as Theodor Bourquin's Grammatik der EskimoSpracbe. ${ }^{14}$

To appreciate the Moravian Collection fully requires some knowledge of the Labrador Inuit and/or a history of Protestant missions. For the uninitiated user, however, there are several basic texts available. Hamilton's History of the Moravian Cburch ${ }^{15}$ remains the definitive history in the English language of the Moravian Church despite its tendency to gloss over past errors. Older histories of the Moravian mission enterprise, such as Spangenberg's Account of the Manner in which the Protestant Church of the Unitas Fratrum, or United Brethren, Preach the Gospel, ${ }^{16}$ Loskiel's History of the Moravian Mission Among the Indians in North America ${ }^{17}$ or the earlier edition of $1794^{18}$ present other and more detailed pictures of the North American mission, one of several Moravian mission fields.

\section{Conclusion}

The Moravian Collection, although most certainly not the complete library of the Moravian missionaries in Labrador, offers the researcher a view of life at Hopedale or Nain or any of the other missions. For a study of the native peoples of Labraclor or the missions there, it complements and augments very capably and creatively collections of similar material at the Centre for Newfoundland Studies at Memorial University of Newfoundland or the collection of primary and secondary materials at the Moravian Archives in Bethlehem, Pennsylvania.

The primary value of the collection lies in its contribution to the study of Christian missions to the native peoples of Canada. The Moravian mission to the Inuit of Labrador represents but a small part of the picture: Protestant and Roman Catholic missions dotted the Canadian landscape from east to west. To the north on Baffin Island. the mission directed by the Anglican Peck was instrumental in bringing Christianity to the Inuit in that part of Canada. To the south, in Ontario and the Maritimes, Christian missions brought the message of the Gospel, and of European life, to the Indians living there.

In this and the last century, missionaries were able to reach the hitherto unreachable native peoples in Canada's northwest. Roman Catholic and Protestant missionaries, by this time often themselves Canadians, travelled far into the north and northwest in order to share their faith with others. Gradually their story is becoming known and documented - like that of the Moravians in Labrador. Collections such as the Moravian Mission to the Eskimos of Labrador and its companion collection, the Canadian Indian Collection, provide the researcher with valuable primary and secondary source material relating to Canada's native peoples and the spread of Christianity among them. 


\section{Notes}

1. Extract from the journal of the Rev. E. J Peck from July 22, 1909 to Oct. 1, 1909. G.1, C.1/0 1909, No. 73. Archives, Church Missionary Socicty, University of Birmingham.

2. Peck was employed by the CMS although since 1908 the mission on Baffin 1sland was administered by the Anglican Bishop of the Diocese of Moosonec. G.1, C. 1/P4 1906-26, 1930, Feb. 18, 1908. Archives, Church Missionary Society, University of Birmingham.

3. An examination of a recent map of Labrador will reveal that Zoar and Okak no longer exist. When the natural resources of an area became insufficient to meet the needs of that community for food, shelter and income, that community was closed.

4. Several theses and monographs have been written on the subject. The reader might wish to consult Diamond Jenness, Eskimo Administration III. Labrador (Montrcal: Arctic lnstitute of North America, 1965); Helge Kleivan, The Eskimos of Northeastern Labrador: a History of Eskimo-Wbite Relations 1771-1955 (Oslo: Norsk Polarinstitutt, 1966); or Carol Brice-Bennett, "Two Opinions: Inuit and Moravian Missionaries in Labrador, 1804-1860" (thesis, Memorial University of Newfoundland, 1981).

5. A comprchensive account of the history of the Moravian Church may be found in J. T. Hamilton and K. G. Hamilton, History of the Moravian Cburcb: the Renewed Unitas Fratrum, 1722-1957 (Bethlehem, Pa.: Moravian Church in America, lnterprovincial Board of Christian Education, c1967).

6. B. Richling, "Hard 'limes Them 'Times: an Interpretative Ethno-history of Inuit and Settlers in the Hopedale District of Northern Labrador, 1752-1977" (diss., McGill University, 1978)

7. Fishermen (usually of British or Irish origin) settled with their families along the coast of Labrador where they maintained a meagre existence. Their numbers remained relatively small until this century.

8. W. H. Whiteley, "Inventory of Moravian Mission Records from Labrador", (St, John's, Nfld.: Memorial University of Newfoundland, 1960 - typescript.)
9. Although listed in a descriptive catalogue, the collection has just recently been fully catalogued and made accessible through McGill's online catalogue (MUSE).

10. It might be noted that the Moravians used the Roman alphabet in transcribing the language of the Labrador Inuit, not syllabics as did many missionaries in the Canadian Arctic.

11. Joseph Romig. A Medical Handbook for Missionaries in Cold Climates (Philadelphia: Boericke \& Tafel, 1904).

12. The English version, Peviodical Accounts (1790-1970), one of the earliest and longest-lived missionary journals, gives much the same valuable information on the history of the Moravian missions worldwide. It is not included in the Moravian Collection.

13. David Zeisberger. Grammar of the Language of the Lenni Lenape or Delware Indians. (Philadelphia: James Key, 1830).

14. Theodor Bourquin. Grammatik der Eskimo-Spracbe... (london: Moravian Mission Agency, 1891).

15. John Taylor Hamilton and Kenneth (i. Hamilton, History of the Moravian Cburch: The Renewed Unitas Fratrum, 1722-1957 (Bethlehem, Pa.: Interprovincial Board of Christian Education, Moravian Church in Amcrica, 1967)

16. August Gottlicb Spangenberg. An Account of the Manner in which the Protestant Church of the Unitas Fratrum, or United Brethren, Preach the Gospel. (Iondon: H. Trapp, 1788).

17. George Henry Loskiel. History of the Moravian Mission Among the Indians in North America (London: T. Allman, 1838).

18 History of the Mission of the United Brethren Among the Indians of North America (London: Brethren's Society for the Furtherance of the Gospel, 1794). 